UNIVERSITY

OF DEBRECEN

FACULTY OF

HEALTH

NYÍREGYHÁZA

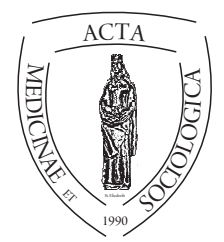

ACTA

MedSoc

VOLUMe 3.

2012

\title{
Eradikációs kezelés hatása vashiányos vérszegénység lefolyására Helicobacter Pylorival fertőzött betegeknél
}

\author{
Albók Éva, Chopey Iván, Fábry Zoltán \\ Ungvári Nemzeti Egyetem, Orvosi Továbbképző Központ, \\ Belgyógyászati és Családorvosi tanszék, Ungvár, Ukrajna
}

\begin{abstract}
Efficiency estimation of eradication therapy in Helicobacter pylori-infected patients with concomitant iron deficiency anemia.

The cause of the development of many chronic gastrointestinal diseases is Helicobacter pylori (HP). The results of researches conducted in the past show that HP can be a starting factor in the development of not only gastro duodenal diseases, but also iron deficiency anaemia, prevalence of which incessantly grows in whole world. Thus, the Maastricht Consensus-III (2005) recommends eradication therapy for all patients with iron deficiency anaemia (IDA) associated with HP. This article contains some published results of our own researches, which aimed to investigate the influence of eradication therapy by different schemes on infected HP patients' blood values without use of iron replacement therapy.
\end{abstract}

Keywords: iron deficiency anaemia, Helicobacter pylori, iron metabolism, eradication therapy, iron replacement therapy

DOI: $10.19055 / \mathrm{ams} .2012 .3 / 4-5 / 7$

A vashiányos vérszegénység (VV) világszerte az egyik leggyakoribb hiánybetegség. Előfordulása a különbözố országokban más anémia típusokhoz viszonyítva is magas - közel 75-85\% [1,2]. Klasszikus leírás szerint microcytaer, s elkülönítendô a thalassaemiától, a sideroblastos anaemiától és a krónikus betegségekkel összefüggó, illetve ólommérgezés következményeként fellépó anaemiától [42]. 
A VV megelőzése kulcsfontosságú bármely társadalmon belül, mivel ezen kóros folyamat jelentôsen súlyosbíthatja más heveny vagy krónikus megbetegedés lefolyását, gátolja az érzékszervek optimális múködését folyamatosan csökkentve azok funkcionalitását, terhességi és szülési szövődményeket is okozhat, gyermeknél és kamaszoknál pedig kedvezôtlenül befolyásolhatja a mozgásbeli és a mentális fejlôdést. A felnôttek vérszegénysége azért is különösen káros mivel jelentôsen csökkenti a munkaképességet, valamint annak minôségét, ezzel évente komoly gazdasági károkat okozva az érintett országokban.

Prevalenciája különbözô népességi csoportokban 2\% és közel $20 \%$ között változik, ezáltal komoly fejtörést okozva minden nemzetiség egészségügyi szakembereinek az adott ország fejlettségi szintjétől függóen. A WHO utóbbi évek adatai alapján arra a következtetésre jutott, hogy VV és/ vagy latens vashiány (LV) tapasztalható a Föld lakosságának 66-80\%-nál. Ezen lakosság 33\%-a reproduktív korban lévố nô, 39\% - gyermek (26\% 1-6 éves) [1,2,42].

Az Egyesült Államokban a VV prevalenciája jelentôs kortól, nemtôl és rassztól függő eltéréseket mutat. Annakidején aktuálisnak vélve a kóros folyamattal való harcot egészségügyi kampány kezdődött „Healthy People 2010” elnevezéssel, melynek célja az volt, hogy 2010-re a vashiányos vérszegénység előfordulási arányát rassztól függetlenül $5 \%$ alá szorítsa a kisdedek, $1 \%$ alá az óvodáskorúak és $7 \%$ alá a fogamzóképes korú nók körében [43]. A kampány alapfeladatai viszont csupán részben teljesültek, a VV jelenleg is nagymértékben jelen van a világ összes országában.

Ezen negatív tendenciákat figyelembe véve a WHO a 2000. évben hemoglobinjavító programot fejlesztett ki az egész földkerekség számára, melynek pontjai egyelőre, sajnos, csupán elméleti jelentôséggel bírnak [2].

A UNICEF és a WHO 2006-ban együttes erôvel igyekezett nemzetközi figyelembe helyezni a VV és LV globális megelôzésének fontosságát, felhívást intézve a világ összes egészségügyi minisztériumának, hogy saját nemzeti és területi sajátosságait figyelembe véve dolgozzanak ki olyan programokat, melyekkel a 2010. évre legalább egyharmadára csökkenthetô a fent említett kóros folyamat prevalenciája $[1,2]$.

Ukrajnában a VV előfordulása szintén igen magas, sajnos a nemzeti prevenciós programok ellenére is mára soha nem látott méreteket öltött.

Az Ukrán Egészségügyi Minisztérium adatai alapján a vérszegénység elterjedtsége 2008-ban 2,1 megbetegedés volt (1000 lakosra számítva). Leggyakoribb előfordulása a VV-nak a Vinnyicai, Ternopoli, Ivano-Frankovszki, Cserkasszi és Kárpátaljai területeken van. Ugyanakkor a VV és LV prevalenciája Ukrajnában jelentősen magasabb a fent említett összmutatótól, 2008-ban elérte a 88\%-ot (!) [4,7].

Emellet még egy fontos tényező került napvilágra az elmúlt években: a felnôtt korban diagnosztizált VV és LV közel 30\%-nál nem sikerült megállapítani a kóros folyamat etiológiai tényezójét [4], amely felveti a kérdést: nem állhat-e valamely, Ukrajnában gyakori prevalenciával bíró kóros folyamat ezen meghatározatlan eredetű VV-ek mögött? 
Az utóbbi évek során egyre többet hallhatunk a Helicobacter pylori (HP) nevezetủ kórokozóról, melynek előfordulása mind világszerte, mind Ukrajnában is igen magas [5-7].

A HP-fertôzés a Föld lakosságának nagyjából felét érinti, a transzmisszió fooként gyermekkorban történik [25]. Leggyakoribb prevalenciával főként a fejlődő országokban találkozunk (70-80\%), leginkább azokban a szociálisan hátrányos helyzetú családokban, ahol valamelyik családtag már fertőzött. A fejlettebb országokban a HP elterjedtsége jóval alacsonyabb, kb. 20-40-ot tesz ki\% [6,25]. Magyarországon a szeroepidemiológiai felmérések szerint az előfordulás a kettő között van, kb. 52-63\%, bár az elmúlt évek során alkalmazott eradikációs kezelések eredményeként inkább az alacsonyabb mutatóhoz közelít [41].

Igen érdekes képet mutat a korcsoportok szerinti HP-prevalencia megoszlás különbözô országok adatai szerint. A fejlődő országokban a 2 éves korú gyermekek kétharmada fertőzött, míg a fejlett országokban a HP-fertőzöttség gyakorisága még a 10 éveseknél is csupán 10\%-os. Elóbbieknél a lakosság 15-20 éves korban 90\%-ban (!) fertôzött, az utóbbiaknál pedig 40 éves kor alatt a lakosság 20\%-a, 60 éves kor felett pedig 50\%-a fertôzött [41].

Ukrajnában a HP-fertőzöttség, a VV és LV-hoz hasonlóan - igen magas, 65-85\%. Gyakrabban fordul nagyvárosi lakosoknál $(52,4 \%)$, ritkábban vidéki területeken $(38,6 \%)[4,7]$.

Különbözô országok kutatói egyre gyakrabban vizsgálják - és többnyire bizonyítják - a HP-t nem-gasztrointesztinális lokalizációjú negatív hatásait [4-6,8,23,2829,31]. Így, az utóbbi évek során több szerzô is feltételezi HP szerepét a VV esetleges kialakulásában is [5,9-22,24,26-27,30,32-40]. Bár egybehangzó következtetés eddig még nem született, mára már több, tudományosan megalapozott elmélet is van arról, miképpen hathat a HP a VV és LV kialakulására. Az elmúlt évek tematikus kutatásai, és azok eredményeit a 1. sz. táblázatban foglaltuk össze.

Figyelembe véve az aktuális nemzetközi kutatások eredményeit, számunkra is igen érdekessé vált, kapcsolatban lehet-e a magas HP-prevalencia a szintén magas VV-prevalenciával, valamint: állhat-e a HP-fertôzöttség a fent említett ismeretlen eredetû VV-ek mögött Ukrajnában?

Vizsgálatunk feladatai: 1. Megállapítani a HP-fertőzöttség gyakoriságát a kárpátaljai felnőtt lakosság körében. 2. Meghatározni az ismeretlen eredetű VV elôfordulásának gyakoriságát HP-val fertôzött személyeknél. 3. Összehasonlítani a HP-fertôzött nem anémiás, valamint VV-ban szenvedő betegek klinikai állapotát, meghatározni azok vérkép-mutatóinak különbözôségeit. 4. Feltárni az eradikációs kezelés esetleges közvetlen, avagy közvetett hatását a HP-val fertôzött, vérszegény betegek klinikai állapotára, vérkép-mutatóira, valamint a VV általános lefolyására.

A vizsgálat folyamata, felhasznált vizsgálati módszerek:

1. lépés: HP-fertőzöttség meghatározása. A HP-pozitív, és negatív betegek vérképmutatóinak összehasonlítása. 


\begin{tabular}{|c|c|c|c|}
\hline № & $\begin{array}{l}\text { Szerzők, hely, a vizs- } \\
\text { gálat idôpontja }\end{array}$ & $\begin{array}{l}\text { Vizsgált } \\
\text { személyek } \\
\text { száma }\end{array}$ & Következtetések \\
\hline 1. & $\begin{array}{l}\text { Shafiqul A. Sarker, et } \\
\text { al India, } 2004 \text { [39] }\end{array}$ & 25 & $\begin{array}{l}\text { A HP-pozitív gyermekpáciensek vas- } \\
\text { abszorpciója a HP-negatívakkal össze- } \\
\text { hasonlítva nem volt szignifikánsan ala- } \\
\text { csonyabb. }\end{array}$ \\
\hline 2. & $\begin{array}{l}\text { Seo J.K. et al, Korea, } \\
2002[38]\end{array}$ & 693 & \multirow[t]{5}{*}{$\begin{array}{l}\text { A HP-pozitív betegek feritin-szintje } \\
\text { alacsonyabbnak bizonyult a } \mathrm{HP} \text { - } \\
\text { negatívakéhoz viszonyítva. }\end{array}$} \\
\hline 3. & $\begin{array}{l}\text { Berg G. et al, Német- } \\
\text { ország, } 2001[11]\end{array}$ & 1806 & \\
\hline 4. & $\begin{array}{l}\text { Milman N. et al, Dá- } \\
\text { nia, } 1998[32]\end{array}$ & 2794 & \\
\hline 5. & $\begin{array}{l}\text { Parkinson A. J. et } \\
\text { al,USA, } 2000[35]\end{array}$ & 2080 & \\
\hline 6. & $\begin{array}{l}\text { Choe J.H. et al, Ko- } \\
\text { rea, } 2001[14-16]\end{array}$ & 220 & \\
\hline 7. & $\begin{array}{l}\text { Ashorn M. et al, } \\
\text { Finnország, 2001[8] }\end{array}$ & 8 & $\begin{array}{l}\text { Sikeres eradikáció után a megfigyelt } 7 \\
\text { VV-ben szenvedó gyermek közül 4-nél } \\
\text { hematológiai javulás következett be. }\end{array}$ \\
\hline 8. & $\begin{array}{l}\text { Choe J.H. et al, Új } \\
\text { Zéland, } 2003 \text { [17] }\end{array}$ & 1060 & $\begin{array}{l}\text { Nem volt szignifikáns különbség a HP- } \\
\text { pozitív,- és negatív betegek feritin- } \\
\text { szintjének összehasonlítása-kor. }\end{array}$ \\
\hline 9. & $\begin{array}{l}\text { Peach H.G. et al, } \\
\text { Ausztrália, } 1998 \text { [36] }\end{array}$ & $\begin{array}{l}\text { Különbözó } \\
\text { korú nók }\end{array}$ & $\begin{array}{l}\text { Szignifikánsan magasabb feritinszint a } \\
\text { HP-pozitív nőknél. }\end{array}$ \\
\hline 10. & $\begin{array}{l}\text { Kohno M. et al, Ja- } \\
\text { pán, } 2000 \text { [30] }\end{array}$ & that & $\begin{array}{l}\text { Refrakter kamaszkori anémia klinikai } \\
\text { és laboratóriumi tünetreduk-ciója sike- } \\
\text { res eradikáció után. }\end{array}$ \\
\hline 11. & $\begin{array}{l}\text { Toyonaga A. et al, } \\
\text { Japán, } 2000[40]\end{array}$ & 365 & $\begin{array}{l}\text { Magasabb vasfelszívódási mutatók a } \\
\text { HP-negatív személyeknél. }\end{array}$ \\
\hline 12. & $\begin{array}{l}\text { Annibale B. et al, } \\
\text { Olaszország, } 1999[9]\end{array}$ & 30 & $\begin{array}{l}\text { VV tünetredukció az eradikáció utáni } \\
12 \text { hónapra. }\end{array}$ \\
\hline 13. & $\begin{array}{l}\text { Collet J.A. et al, } \\
\text { Ausztrália, } 1999 \text { [31] }\end{array}$ & 1064 & 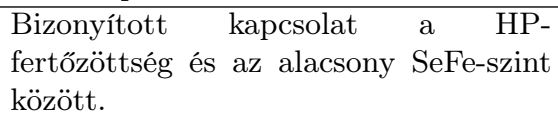 \\
\hline
\end{tabular}

1.sz táblázat. Összefoglaló táblázat az utóbbi évek során végzett HP és VV közötti kapcsolattal foglalkozó vizsgálatokról, azok eredményeiról.

Még az 1. lépés folyamán kizártuk azokat a betegeket, akik olyan ismert patológiában szenvedtek, amelyek megalapozhatták a VV kialakulását, mégpedig: onkohematológiai megbetegedések, különböző típusú és súlyosságú vérzések, posztoperatív állapotok, gyomorrezekció, heveny fertôzések, onkológiás folyamatok, máj-, vesebetegségek, kollagenózisok. Nem vehettek részt a vizsgálatban terhes nók és kismamák, vegetáriánusok, valamint azon személyek, akik előzőleg allergiás reakciót mutattak a vizsgálat során tervezett eradikációs kezelés bármely komponensére. 
A HP-fertőzöttséget endoszkópos vizsgálat általi CLO-tesztekkel („Pliva Lachema"), HP-antigen cito-stool-teszttel (imunokromatográfiás módszerrel), valamint anti-HP Ig G mennyiségi kimutatásával (immunofermetális elemzés - „ImmunoComb" Orgenics teszt) végeztük. Mindösszesen 171, különbözó korú, felnôtt kárpátaljai lakost vizsgáltunk meg, melyek közül 120 bizonyult HP-fertôzöttnek (70,2\%), ebból 58 nô (48,3\%), és 62 férfi (51,7\%) volt. Az vizsgált betegek átlagéletkora 47,2 év volt, a vizsgált betegek életkora 22-tól 87-ig váltakozott.

A HP-pozitív betegek az 1. csoportba kerültek, a HP-negatívak - a 2. csoportba.

Az összehasonlítást a csoportok átlagos értékei, valamint korcsoportok és nemek közötti felosztás alapján is elvégeztük.

2. lépés. A HP-pozitív VV-ben szenvedô betegek szürése. Az 1. lépés során, a vérkép elemzés alapján meghatároztuk azon betegek számát, akik VV-ban szenvedtek. A 2. lépés folyamán kiszürtük azokat a betegeket, akiknél a diagnosztizált VV ismeretlen eredetû volt, ók képezték a 1şoportot. A meghatározott etiológiájú VV-ban szenvedóket kizártuk a vizsgálat további menetéból egyúttal optimálisabb, differenciáltabb kezelést biztosítva számukra. A közép, és súlyos fokozatú VV képviselőit szintén tervünk szerint ki kellett zárnunk a további vizsgálatokból, viszont a laboreredmények elemzésével a vizsgált személyek között csakis enyhe fokú VV-vel találkoztunk.

A vizsgálati alapcsoportba (1/a) azokat a személyeket soroltuk, akiknek ananmnézisében múltbéli allergiás reakciókat találtunk a tervezett kezelés során alkalmazandó bármely típusú perorális vaskészítményre (emiatt nem szedhették azokat), vagy heveny emésztőszervi panaszaik miatt ellenjavallatokkal rendelkeztek a VV vaskészítményekkel való perorális korrekciójához.

A nem vérszegény HP-fertôzött 1 . csoport maradék képviselőit az 1/b csoportba soroltuk.

A VV szúrésénél a következô diagnosztikai kritériumokat használtuk: hemoglobin-szint - férfiaknál $\leqslant 13,0 \mathrm{~g} / \mathrm{dL}$., nôknél $\leqslant 12,0 \mathrm{~g} / \mathrm{dL}, \mathrm{SeFe}-\leqslant 12 \mathrm{mkmol} / \mathrm{L}$ (immunhemilumineszcens módszer), Se vaskötő-képesség $\leqslant 69 \mathrm{mkmol} / \mathrm{L}$, ferritinszint $\leqslant 30 \mathrm{ng} / \mathrm{ml}$ (immunhemilumineszcens módszer). A betegek vérképeit ugyanazon „Cobas Integra” típusú hemoanalizátoron készítettük.

3. lépés. A HP-pozitív ép vérképú, valamint VV-s HP-fertôzött betegek eradikációs kezelése, azok összehasonlító elemzése.

A HP-fertőzöttség elsôdlegességétől függően két eradikációs sémát alkalmaztunk: 1. Tradicionális triterápia - az elsó alkalommal diagnosztizált HP-pozitív betegek esetében: omeprazol - $20 \mathrm{mg}$ 2x/nap, amoxicillin 1,0x2/nap, klaritromicin - 500mgx2/nap. 2. „5+5” séma - reinfekció esetén: első 5 nap - omeprazol $20 \mathrm{mg}$ 2x/nap, amoxicillin - 1,0x2/nap, majd a köv. 5 nap - omeprazol - $20 \mathrm{mg}$ 2x/nap, klaritromicin - 500mgx2/nap, tinidazol - $500 \mathrm{mg}$ 2x/nap. Az eradikációs kezelés javítására, valamint a kezelés utáni mikroflóra-károsodás helyreállítására minden betegnél ugyanazon probiotikum-készítményt alkalmaztuk. Az eradikáció sikerességét a kezelés utáni 4 . héten végeztük HP-antigen cito-stool-teszttel (immunkromatográfiás módszerrel). 


\section{Eredmények}

A fent említett módszerek segítségével megállapítottuk, hogy az általunk megvizsgált, diszpepsziás panaszokkal küszködő betegek igen magas arányban szenvednek HP-fertôzöttségtól. A 171 felnôtt kárpátaljai lakos közül 12o bizonyult HPfertôzöttnek (70,2\%). Ezzel egy igen magas prevalencia-mutatót kaptunk, amely, sajnos, alátámasztja az Ukrajnára vonatkozó mutató átlagos értékét is.

Főbb hangsúlyt szerettünk volna fektetni a betegek laboratóriumi értékeinek elemzésére. Összehasonlítottuk az 1. és 2. csoport képviselóinek vérképmutatóit, miáltal kiderült (1. sz. ábra), hogy a HP-pozitív betegek hemoglobin-szintje átlagosan 133,6 $\pm 5,06 \mathrm{~g} \backslash \mathrm{L}$ volt, vagyis - jelentôsen és szignifikánsan alacsonyabb volt a HP-negatívak ugyanazon mutatóitól (153,5 $\pm 6,36 \mathrm{~g} \backslash \mathrm{L})$.

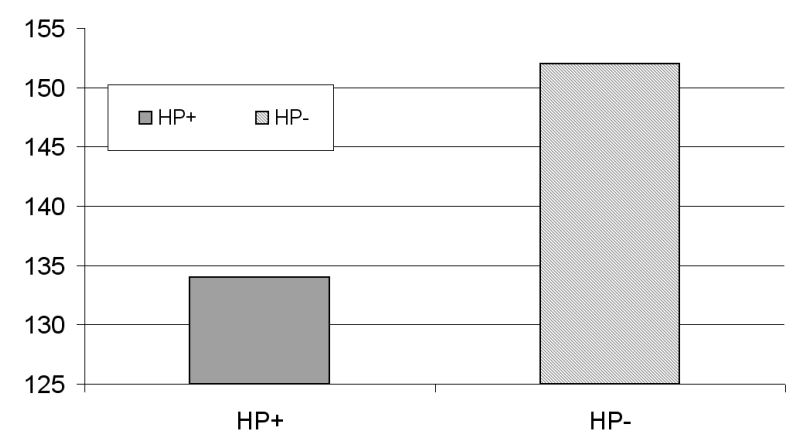

1. ábra. A HP+és HP- betegek átlagos hemoglobin-szintjének (g\L) összehasonlítása $(\mathrm{p}<0.05)$.

A betegek vasháztartását jellemzô laborértékeit megvizsgálva kiderült, hogy a VV előfordulása jóval gyakoribb a HP-pozitív betegeknél $(27,5 \%)$ a Hp- személyekhez viszonyítva (5,9\%). Ugyancsak le kell szögeznünk, hogy a HP-negatív betegeknél minden esetben (3) sikerült meghatároznunk a VV kialakulásának pontos okát, míg a HP-pozitív VV-ben szenvedókrôl nem mondhatjuk el, hiszen közöttük 33 esetből csupán 4 (12,1\%) esetben találtunk HP-n kívül más feltételezhetô etiológiai tényezôt.

Tovább elemezve a betegek labormutatóit, összehasonlítást végeztünk a HPpozitív és HP-negatív személyek ferritin-szintjérôl, s kiderült, hogy a pozitív személyeké szignifikánsan alacsonyabb volt $(\mathrm{p} \leqslant 0,05)$. A szervezet vasháztartását jellemzô labormutatókat vizsgálva kíváncsiak voltunk arra, hogy léteznek-e nemtôl függố különbségek, s a csökkent átlagos ferritin-szintet nem csupán a nôi nem képviselôinek laborértékei okozzák-e? Hogy kiderítsük, elôször a HP-fertôzöttséget nem véve figyelembe, az vizsgálati csoportot felosztottuk nemek szerint, s amint azt a 2. sz. is ábra jellemzi, a nối csoportnál kissé alacsonyabb (ám nem szig- 
nifikáns) ferritin-értékeket $(39 \pm 21 \mathrm{ng} / \mathrm{mL})$ kaptunk az férfiak ugyanazon átlagos értékénél $(48 \pm 19 \mathrm{ng} / \mathrm{mL})$.

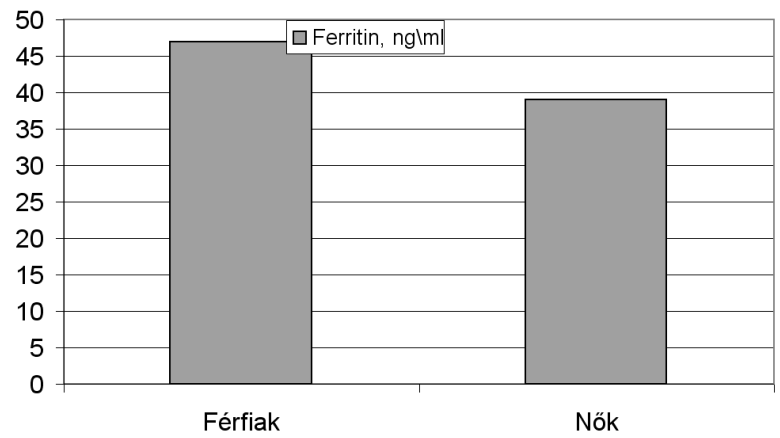

2. ábra. A megvizsgált betegek átlagos ferritin-értékeinek nemek szerinti megoszlása (magyarázat a szövegben).

Bár az eltérés nem öltött szignifikáns méretet, mégis szükségesnek találtuk, hogy nemeket-, és HP-fertőzöttséget együttesen figyelembe véve elemezzük a kapott laboreredményeket, melyeket a 3 . sz. ábra jellemez.

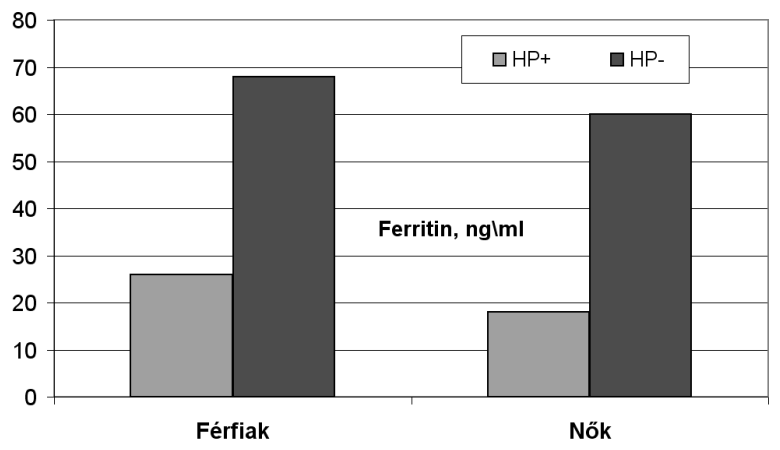

3. ábra. A megvizsgált betegek átlagos ferritin-értékei nemek, - valamint HPfertőzöttség szerinti megoszlása (magyarázat a szövegben).

Mint láthatjuk, a HP-pozitív személyek átlagos ferritin-szintje nemcsak a nôi nem mutatói által volt szignifikánsan alacsonyabb, hiszen a HP-pozitív férfiak ferritin-átlagértékei is jelentôs csökkenést mutattak HP- férfitársaikhoz viszonyítva. Ennek eredményeképpen leszögezhetjük, hogy kiszúrve a vizsgálati csoportból a nôgyógyászati megbetegedésekben szenvedő nôket, olyan szelektált nói csoportokat 
kaphattunk, amelyeknél, bár kissé alacsonyabb vasháztartás-mutatókat kaptunk a férfi csoportokhoz viszonyítva, ám ezen értékek nem mutattak szignifikáns különbséget a férfiak azonos HP-csoportjainak átlagértékeihez viszonyítva, viszont szignifikáns különbséget adtak a nemen belüli HP-fertőzöttség utáni felosztáskor.

Érdekes törvényszerúségre bukkantunk, amikor különbözô korcsoportokra osztottuk a 1. csoporthoz tartozó betegeket (HP-fertôzött), majd megvizsgáltuk azok vörösvérsejt-, és hemoglobin-szintjüket. A kapott eredményeket az 4. és 5 . ábrákon tüntettük fel.

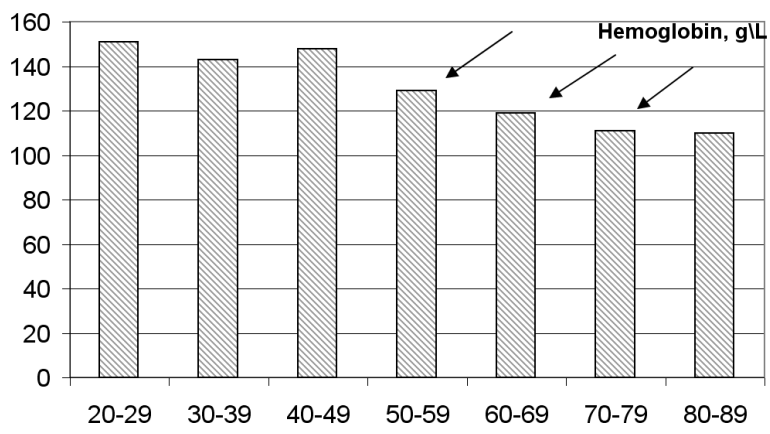

4. ábra. A vizsgált személyek hemoglobin- , és átlagos vörösvérsejtszintje korcsoportoktól függő́n (magyarázat a szövegben).

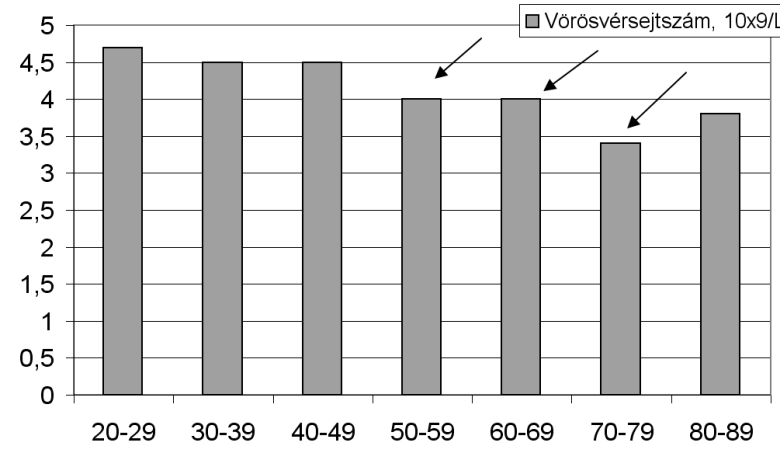

5. ábra. A vizsgált személyek hemoglobin- , és átlagos vörösvérsejtszintje korcsoportoktól függóen (magyarázat a szövegben).

Mint láthatjuk, a HP-pozitív betegek hemoglobin-szintje fordítottan arányos a betegek korával (p<0.05, az 50 év fölötti korosztályoknál, a fiatalabb korosztálycsoportok értékeihez viszonyítva). 
Hasonló tendenciát mutatott a HP-fertőzött betegek vörösvérsejt-szintje is, bár ezen mutató szignifikáns különbséget csupán a jóval idősebb korosztálynál mutatott $(\mathrm{p}<0.05$, a 70 év fölötti korosztálynál, a többi korosztálycsoport értékeihez viszonyítva).

Miután más törvényszerüséget nem találtunk a betegek labormutatóit vizsgálva, hozzáláttunk a HP-fertôzöttek eradikációs kezeléséhez a fent említett diferenciált eradikációs sémákat alkalmazva.

Az alkalmazott kezelést minden beteg viszonylag jól viselte, és bár néhány esetben enyhe hányinger, fejfájás, étvágycsökkenés jelentkezett, ezek intenzitása igen enyhe jellegú volt, így a HP-pozitív betegek mindegyike 100\%-ban teljesítette a javasolt kezelési programot.

Az elvégzett kezelés eredményességét az eradikáció utáni 4. héten végeztük el. A tradicionális kombinációval kezelt betegek eradikációs eredményessége $86 \%$ volt, míg az , $5+5$ " sémával eradikált páciensek kezelési eredményessége jóval magasabb $92 \%$ volt. A sikertelen eradikációs betegeket a vizsgálati csoportokban hagyva, probiotikumokkal utókezelve tovább figyeltük, a sikeresen eradikált betegekkel együtt, majd a vizsgálat lezártával szelektívebb sémát alkalmazva kezeltük.

A megfigyelést az eradikáció utáni 1., 3., 6., 10. hónapok folyamán végeztük a betegek klinikai állapotát, valamint előzóleg már összehasonlított laborértékeit vizsgálva. A kapott eredményeket a 6 . sz. ábrán közöltük.

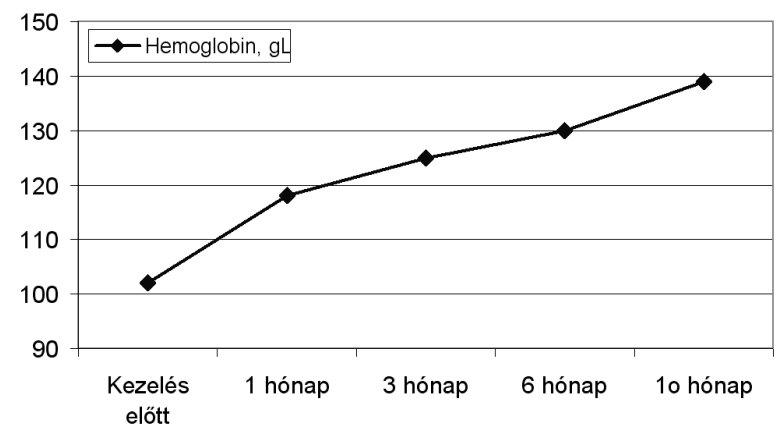

6. ábra. A kezelt betegek átlagos Hg-szintjének változása az eradikáció utáni időszakban ( $<<0.05$ - a kiindulási és köztes pontok közötti azonos szakaszokban).

Mint láthatjuk, a HP-pozitív, VV betegeknél, már az 1 hónap végeztével pozitív dinamikát tapasztalhatunk, vaskészítmények alkalmazása nélkül, a további hónapok folyamán ezen javulás szignifikáns méreteket öltött a kezdeti értékekhez viszonyítva $(\mathrm{p} \leqslant 0,05)$.

Megfigyeltük a kezelt betegek átlagos feritin-szintjének változását is ugyanazon megfigyelési szakaszokban, azt tapasztaltuk, hogy az említett laboratóriumi átlagérték úgyszintén növekedett a megfigyelési idôszak elteltével, s már a 3 hónap vé- 
gére szignifikáns különbséget mutatott a kiindulási átlagértékhez viszonyítva (lásd 7 sz. ábrán). Ugyanakkor azt is le kell szögeznünk, hogy az említett laborérték normalizálódása nemcsak a HP-pozitív, VV betegeknél volt tapasztalható. A 7 sz. ábrából kifolyólag elmondhatjuk, hogy a HP-pozitív, nem vérszegény betegek ugyanazon labormutatói szintén szignifikánsan növekedtek a kezdeti, kiinduló értékekhez viszonyítva $(\mathrm{p}<0,05)$. S bár ennél a csoportnál nem beszélhetünk VV-ról, világosan látszik, hogy az alkalmazott eradikációs kezelés igen sokat javított kissé megcsappanó félben lévő vaskészletükön.

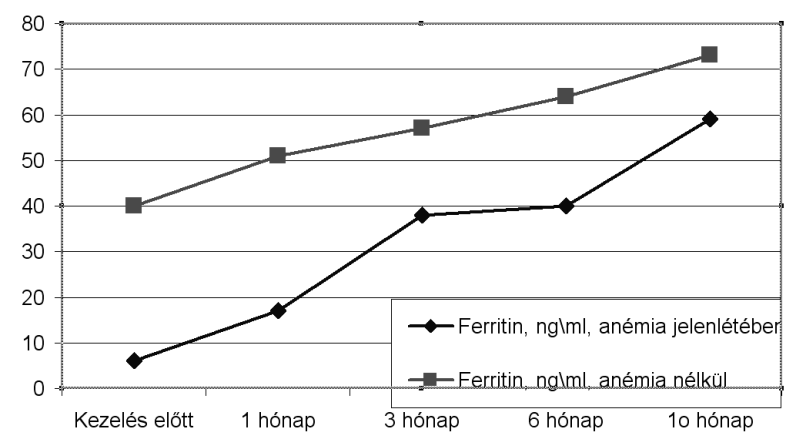

7. ábra. A kezelt betegek átlagos feritin-értékeinek változása az eradikáció utáni időszakba. ( $<<0.05$ - a kiindulási és 3.hánapot jellemzố csomópontoktól számítva - a VV-ben szenvedố betegeknél, p $<0.05$ - a kiindulási és 6. hónapot jellemzô csomópontoktól számítva - a VV-ben nem szenvedő eradikált betegeknél).

Érdekesnek találtuk megvizsgálni, lehetnek-e átlagos laborérték-különbözôségek az eradikációs kezelés típusától függően? Függhet-e a vérkép-javulás egyértelmüen az eradikáció eredményességétől, gátolhatja-e jelentôsen a laborértékek javulását a HP további perszisztálása a vizsgálati csoportok egyes képviselőinél? A kapott eredményeket a 8. sz. ábra jellemzi.

Mint láthatjuk, a laborértékek javulása egyenes korrelációt mutatott az eradikációs kezelés eredményességével, a megfigyelt értékek egyértelmúen jobb dinamikát mutattak az , $5+5$ " sémával kezelt betegeknél, ahol jóval magasabb volt az eradikáció eredményessége.

Következtetésképpen leszögezhetjük, hogy mint a kárpátaljai betegek példáján is egyértelmúen bebizonyosodott, hogy a HP-jelenléte jelentősen csökkenti a szervezet vaskészletét, idôvel LV vagy VV-get okozva, s a sikeres eradikációval megelőzhetố eme, szinte már epidemiás méreteket öltött patológiás állapot kialakulása, avagy eredményesen kezelhetó a már kialakult, enyhe VV akár vaskészítmények alkalmazása nélkül is. 


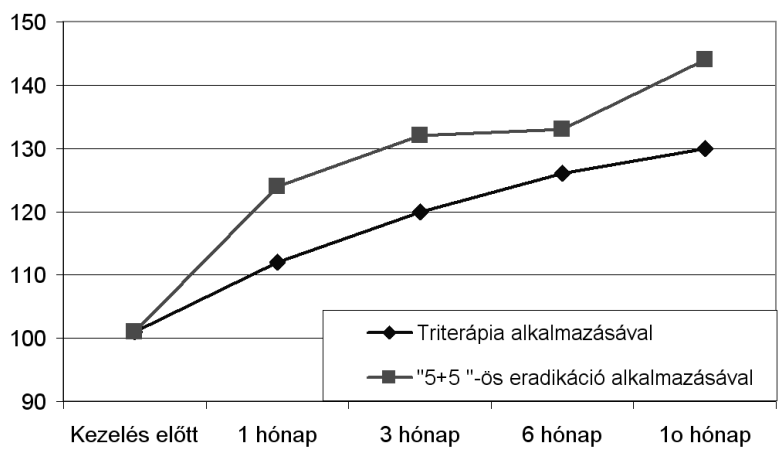

8. ábra. Triterápiás (88\%-os eradikáció) és , $5+5$ "ôs (94\%-os eradikáció) eradikációs sémák diferenciált hatása a VV lefolyására $(\mathrm{p}<0.05$ mindkét csoport kezdeti és végsố (10. hónap) megfigyelési pontja között, a két csoport végsố megfigyelési pontjain tapasztalt értékek nem szignifikánsan különböznek).

\section{Irodalomjegyzék}

1. WHO, 2001: Iron deficiency anaemia: Assesment, prevention and control. Geneva.

2. WHO, 2000: Reg. Off. Eur.: Complementary feeding and control of iron deficiency anemia in the Newly Independent States. Presentation WHO at a WHA/UNICEF consultation - Copenhagen.

3. Бурков В., Бурдина Г. 2006: Инфекция Helicobacter pylori c позиции практического врача. Киев. «Здоров'я».

4. Гайдукова С., Выдыборець С., Сиван Л., Шприниян Т.: Железобефищитная анемия: современные подходы к диагностике и лечению, K., «Здоров'я». 32 ст.

5. Дотарадський И.В., Исаков В.А., Татасаускас А.А.: Внежелудочные ефекты Helicobacter pylory: продолжение инфекционного ,,ренесанса"? Рос. журнал гастроентерологии, генатологии, колопроктологии. - 2000. №2. C. $16-22$.

6. Исаков В. Дотарадский И.: Хеликобактериоз. Москва, «Медкнига». 231 ст.

7. Федорук А., Некрасова Н. Вороб'єв П.: Оцінка типічноӥ практики лікування залізодефіцитної анемії у хворих похилого віку в умоваш ноліклі ніки. Нове в гепатології та трансфузіологіі. 2004. №1. - С. 128-132.

8. Altshuler E.: Association of Helicobacter pylori infection and Parkinson"s disease already proposed. - Acta.Neurol.Scand. - 1999. - №100. - p. 122-128.

9. Annibale B., Marignami M., Monarca B. et al. : Reversal of iron deficiency anaemia after Helicobacter pylori eradication in patients with asymptomatic gastri- 
tis. - Ann.Intern.Med. - 1999. - №131. - p. 668-740.

10. Barabino A: Helicobacter pylori-related iron deficiency anemia: a review.

Helicobacter. - 2002. - №7(2). - p. 71-76.

11. Berg A: Helicobacter pylori infection and serum ferritin:a population-based study among 1806 adults in Germany. - Am.J.Gastroenterol. - 2001. - №96. - p. 1014-1024.

12. Bini E.J.: Helicobacter pylori and iron deficiency anemia: guilty as charged? Am.J.Med. - 2001. №111. - p. 495-502.

13. Byrd T. Horwitz M.: Regulation of transferin receptor expression and ferritin content in human mononuclear phagocytes: coordinate upregulation by iron transferin and down-regulation by interferon gamma. - Clin.Invest. - 1999. - №91. - p. 969-972.

14. Choe J., Kim S., Hong I.: The relationship between Helicobacter pylori infection and iron deficiency: seroprevalence study in 937 pubescent children. - Arch. Dis. Child. - 2003. №88(2). - p. 178-183.

15. Choe J., Kwon J., Jung M. et al.: Helicobacter pylori-associated iron deficiency anemia in addescent female athletes. - J. Pediatr. - 2001. - №139. - p. 100-104.

16. Choe Y., Hwang T., Kim H. et al.: A possible relation of the Helicobacter pylori pfr gene to iron deficiency anemia? - Helicobacter. - 2001. - №6(1). - p. 55-64.

17. Choe Y., Oh Y., Lee N. et al:. Lactoferrin sequestration and its contribution to iron-deficiency anemia in Helicobacter pylori-infected gastric mucosa. J.Gastroenterol.Hepatol. - 2003. - №18. - p. 980-985.

18. Dhaenens L, Szczebara F., Husson M.O.: Identification, characterization, and immunogenicity of the lactoferin-binding protein from Helicobacter pylori. - Infect.Immun. - 1997. - №65. - p. 514-522.

19. Dickey W.: Iron deficiency, gastric atrophy and Helicobacter pylori. - Dig. Liver Dis. 2002. - №34. - p. 313-328.

20. Diop S., Aouba A., Varet B: Reversal of iron deficiency anemia after eradication of Helicobacter pylori infection. - Presse Medicale. - 2004. - №33. - p. 1517-1525.

21. Doig P., Austin J.W., Trust T.J.: The Helicobacter pylori 19,6-Kilodaltonprotein is an iron containing protein resembling ferritin. - J.Bcteriol. - 1993 . №75.- p.557-618.

22. Dufour C., Brisigotti M., Fabretti G. et al.: Helicobacter pylori gastric infection and sideropenic refractory anemia. - J. Pediatr. Gastroenterol. Nutr. - 1993. №17. - p. 225-232.

23. Fisher W., Gebert B., Haas R.: Novel activities of the Helicobacter pylori vamolating: from epithelial cells toward the immune system. - Int. J. Med. Microbiol. - 2004. - №293. - p. 539-547.

24. Hacihanefioglu A., Edebali F., Celebi A., et al.: Improvement of complete blood count in patients with iron deficiency anemia and Helicobacter pylori infection after the eradication of Helicobacter pylori. - Hepato-Gastroenterology. - 2004. - №51. p. 313-318. 
25. Hocker M., Hohenberger P.: Helicobacter pylori virulence factors - one part of a big picture. - Lancet. - 2003. - №362. - p. 1231-1233.

26. Husson M.O., Legrand D., Spik G. et al.: Iron acquision by Helicobacter pylori : importance of human lactoferrin. Infect.Immun. - 1993. - №61. - p. 2694-2701.

27. Jilmar A., Candan F., Turan M.: Coffe phagia and iron deficiency anemia: a possible association with Helicobacter pylori. - Health Popul.Nutr. - 2005. №23(1). - p. 102-106.

28. Joshimura M., Hirai M., Tanaka N. et al.: Remission of severe anemia persisting for over 20 years after eradication of Helicobacter pylori in cases of Menetrier"s disease and atrophic gastritis: Helicobacter pylori as a pathogenetic factor in iron-deficiency anemia. - Intern.Med. - 2003. - №42. - p. 971-978.

29. Kerr J., Allkhattaf A., Barson A., Burnie J.: An association between sudden infant death syndrome (SIDS) and Helicobacter pylori. - Arch.Dis.Child. - 2000. №83. p. 429-434.

30. Kohno M., Muraoka S., Takahashi M. ?t al.: Iron deficiency anemia associated with Helicobacter pylori gastritis. - J. Pediatr. Gastroenterol. Nutr. - 2000. - №31. - 52-58.

31. Lehours P., Menard A., Dupont S. et al.: Evaluation of the association of nine Helicobacter pylori-virulence factors with strains involved in low-grade gastric mucosa-associated lymphoid tissue lymphoma. - Infect. Immun. - 2004. - №72. p. $880-888$.

32. Milman N., Rosenstock S., Andersen L. ?t al.: Serum ferritin, hemoglobin, and Helicobacter pylori infection: a seroepidemiologic survey comprising 2794 Danish adults. // Gastroenterology. - 1998. - №115. - p. 268-342.

33. Nahon S., Lahmek P., Massard J.,et al.: Helicobacter pylori-associated chronic gastritis and unexplaned iron deficiency anemia: a reliable association? - Helicobacter. - 2003. - №8(6). - p. 573-580.

34. Odum 1., Andersen L.: Investigation of Helicobacter pylori ascorbic acid oxidating activity. - FEMS immunol. Med. Micribiol. - 1995. - №10. - p. 289-294.

35. Parkinson A., Gold B., Bulkow L. et al.: High prevalence of Helicobacter pylori in the Alaska native population and association with low serum ferritin levels in young adults. - Clin. Diagn. Lab. Immunol. - 2000. - №7. - 885-893.

36. Peach H., Bath N., Farish S.: Helicobacter pylori infection: an added stressor on iron status of women in the community. - Med. J. Australia. - 1998. - №169. - p.188-278.

37. Pellicano R., Rizzetto M. : Is hepcidin the bridge linking Helicobacter pylori and anemia of chronic infection? A researsh proposal. - Panminerva Medica. 2004. - №46. - p. 165-174.

38. Seo J., Ko J., Choi K.: Serum ferritin and Helicobacter pylori infection in children:a sero-epidemiologic study in Korea. - J. Gastroenterol. and Hepatol. 2002. - №17. - p.754-761.

39. Toyonaga A., Okamatsu H., Sasaki K., Kimura H.: Epidemiological study on food intake and Helicobacter pylori infection. - Kurume Med. Journal. - 2000. - 
№47(1). p. 25-30.

40. Shafiqul A. Sarker, Davidsson L., Mahmudet H. et al.: Helicobacter pylori infection, iron absorption, and gastric acid secretion in Bangladeshi children. American Journal of Nutrition. - 2004. - №80(1). - p. 149-153.

41. Veres Gábor, Dr.: Helicobacter pylori fertôzés gyermekkorban. - Gyermekgyógyászat. - 2006. - №10. p. 115-120.

42. Zuckerman K: Approach to the anemias. In: Cecil RL,Goldman L, Ausiello DA. Cecil Textbook of Medicine. 22nd ed. Philadelphia, Pa.: Saunders.

43. Centers for Disease Control and Prevention. Iron deficiency-United States. 1999-2000. : MMWR Morb Mortal Wkly Rep. - 2002. - №51. p. 897-9.

Albók Éva belgyógyász-szakorvos, az orvostudomány magisztere, PhD-hallgató, egyetemi tanár

Chopey Iván belgyógyász-szakorvos, az orvostudomány doktora, professzor, az Ungvári Nemzeti Egyetem Továbbképző Karának dékánja, egyetemi tanár

Fábry Zoltán biokémikus, professzor, nyugalmazott egyetemi tanár 